\title{
QT 間隔の時間的変動と心室性不整脈
}

-QT variability index と周波数解析による検討一

大野則彦* 斎藤寬和* 大坂元久* 新 博次* 高野照夫*

心室性不整脈とQT間隔変動との関連を time domain analysis(TDA)および frequency domain analysis(FDA)により検討した. 対象は持続性心室頻拍または 心室細動を有する(VT/VF) 患者 19 例，VT/VF を有しない心疾患 $(H)$ 患者 19 例，健 常 $(N)$ 者 19 例で，臥位で標準 12 誘導心電図を 10 分間記録し，1 心拍ごとのRR 間隔，QT間隔を自動計測し得られた時系列データよりTDAの指標として QT variability index(QTVI)を, FDAの指標として低周波数帯域(LF)，高周波数帯 域 $(H F)$ のパワー値, RR 間隔変動と $\mathrm{QT}$ 間隔変動の coherence を求め比較し た. QTVIはN群 $(-0.766 \pm 0.331)$ に比しH群 $(-0.119 \pm 0.723)$, VTNF 群

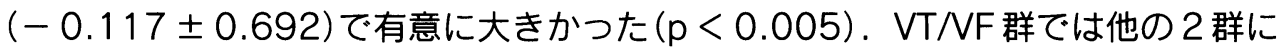
比べ QT 間隔変動の LFパワー值, HFパワ一值は有意に大きく( $\mathrm{N}$ 群 vs H群 vs VT/VF 群 : LF : $28 \pm 12 \mathrm{msec}^{2}$ vs $42 \pm 31 \mathrm{msec}^{2}$ vs $88 \pm 92 \mathrm{msec}^{2} ; \mathrm{p}<$ 0.005 vs $N$ 群, $p<0.05$ vs H群; HF : $45 \pm 21 \mathrm{msec}^{2}$ vs $67 \pm 52 \mathrm{msec}^{2}$ vs $163 \pm 176 \mathrm{msec}^{2} ; \mathrm{p}<0.005$ vs $\mathrm{N}$ 群, $\mathrm{p}<0.01$ vs H群), LFのcoherence は有意に小さかつた ( $N$ 群 vs H群 vs VT/VF群 : $0.329 \pm 0.156$ vs $0.305 \pm$ 0.186 vs $0.163 \pm 0.072 ; p<0.005$ vs $N$ 群, $p<0.01$ vs H群). VT/VF 群 ではQT間隔変動が大きく，交感神経の影響が示唆された。

(心電図, $2002 ; 22: 274 \sim 284$ )

\begin{tabular}{|ll|}
\hline Keywords & - QT 間隔変動 \\
& • 心室性不整脈 \\
& $\bullet \mathrm{QT}$ variability index \\
& - 周波数解析 \\
& - coherence
\end{tabular}

*日本医科大学第一内科

（テ113-8603 東京都文京区千駄木1-1-5）

\section{I ．はじめに}

心臓突然死の多くはその直接死因が致死性不整脈 であるといわれる ${ }^{1)}$. ホルター心電図装着中に突然 死をきたした例をまとめた報告では，83\%が頻脈性 心室性不整脈によるものであった2)。したがって致

Temporal fluctuation of QT interval and ventricular arrhythmia

- QT variability index and frequency analysis of QT interval-

Norihiko Ohno, Hirokazu Saitoh, Motohisa Osaka, Hirotsugu Atarashi, Teruo Takano

2002 年 2 月 6 日 原稿受領 $/ 2002$ 年 6 月 14 日 揭載承認 
死性心室性不整脈の予知は心臓突然死を予防するう えで有用と考えられ，これまでハイリスク患者識別 法として, 左室駆出率 ${ }^{3)}$, 心拍変動 ${ }^{4}$, 圧受容体感受 性 $^{5)}$, 心室遅延電位 ${ }^{6)}$, 心蔵電気生理学的検査 ${ }^{7)}$ な゙ が検討されてきた。

心室性不整脈は心室再分極異常とも深く関連する ことから, 心室再分極過程の評価は心室性不整脈予 知に重要である.これまで心室再分極の空間的不均 一性の指標である QT dispersionが広く研究 ${ }^{8) ~ 10) さ ~}$ れてきたが, 標準 12 誘導心電図の最大 $\mathrm{QT}$ 間隔と最 小QT 間隔の差で表される QT dispersionはその再 現性が低いとする報告 ${ }^{11)}$ や体表面心電図から得られ たQT dispersionと心筋局所より直接測定した dispersion of ventricular repolarization は相関しない とする報告もあり ${ }^{12)}$, 近年その有用性について疑問 視されている ${ }^{13), 14) . ~}$

一方心室再分極の時間的不均一性 (temporal dispersion)の指標として T波の交替現象 ( $\mathrm{T}$ wave alternans：TWA)の検討が広く行われている ${ }^{15) \sim 17)}$. その多くはTWAが心室性不整脈の予知因子として 有用であると報告しているが, 現在臨床的に検討さ れているTWA は主に $\mu$-voltレベルでのTWAで, その計測には特殊な機器を使用しなければならない。

BergerらはQT 間隔時間的変動の新しい指標とし てQT variability index (QTVI)を提唱し, 拡張型心 筋症患者で増大することを報告した ${ }^{18)}$. QTVIは標 準 12 誘導心電図からも測定可能で，アルゴリズムは 明解であるが, その有用性についての検討は少ない。 また，QT 間隔は心拍数の影響のみならず自律神経 の直接的影響 ${ }^{19)}$, 20) も受けるが, 周波数解析による QT 間隔変動を検討した報告は少なく，これまでに 正常者における自律神経調節との関連 ${ }^{21)}$, 22) や心疾患

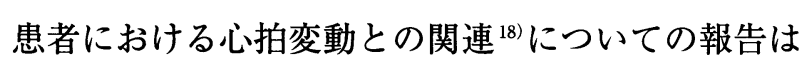
あるが，心室性不整脈患者における QT 間隔変動に ついては明らかではない，そこで我々はQT 間隔変 動をQTVIによる time domain analysis と frequency domain analysisの両面から解析し心室性不整脈との 関連につき検討した。

\section{II. 対象と方法}

1. 対象

対象は各種心疾患で日本医科大学付属病院に入院 し持続性心室頻拍 (30秒以上持続する心室頻拍) また は心室細動が確認された心室性不整脈 (VT/VF) 患 者19例 (男 13例, 女6例), 心室頻拍, 心室細動を有 しない心疾患 $(\mathrm{H})$ 患者 19 例 (男 15 例, 女 4 例), 日本 医科大学付属病院で健康診断を受けた器質的心疾患 を有しない健常 $(\mathrm{N})$ 者 19 例 (男13例，女6例)である (表).VT/VF群では入院時または入院中に標準 12 誘導心電図またはモニター心電図で自然発作の $\mathrm{VT} / \mathrm{VF}$ が確認され, 頻度は 1 回から複数回まで様々 であった，H群では既往歴, 標準 12 誘導心電図, ホ ルター心電図, 運動負荷心電図においてVT/VFは 認めなかった. VT/VF群の基礎心疾患は陳旧性心 筋梗塞 13 例 $(68 \%)$, 拡張型心筋症 2 例 (11\%), 肥大 型心筋症 1 例 $(5 \%)$, ウイルス性心筋炎後の心機能 低下例 1 例 $(5 \%), \mathrm{QT}$ 延長症候群 2 例 (11\%) で, 特 にQT延長症候群はVT/VF 群にのみ含まれた。 H 群の基礎心疾患は陳旧性心筋梗塞 14 例 (74\%), 拡 張型心筋症 4 例 (21\%), 肥大型心筋症 1 例 (5\%) で あった. VT/VF群, $\mathrm{H}$ 群では経胸壁心臓超音波検 査を施行し, 左室駆出率を求めた.

\section{2. 方法}

\section{1)心電図記録}

安静臥位にて標準 12 誘導心電図を 10 分間記録し た.心電計 (フクダ電子社製FDX-6521) を介し, $\mathrm{A} / \mathrm{D}$ 変換器 MP100 (Biopac 社製)にてサンプリング 周波数 $1,000 \mathrm{~Hz}$ で $\mathrm{A} / \mathrm{D}$ 変換後パーソナルコンピュー ターに取り达んだ.デジタル信号に変換した心電信 号を循環動態全自動解析システム・フラクレット (大日本製薬社製)に転送し一心拍ごとの RR 間隔, QT 間隔を計測した. フラクレットの計測アルゴリ ズムは以前に報告されている ${ }^{23), 24)}$. 計測した誘導は 胸部 $V_{2}$ 誘導または $V_{5}$ 誘導で $T$ 波がより認識しやす い誘導とした。また期外収縮については前後一心拍 を含め解析より除外した。 心房細動, 脚ブロック例 


\section{表 患者背景}

\begin{tabular}{|c|c|c|c|c|}
\hline & $N$ 群 $(n=19)$ & H群(n=19) & VT/VF群(n=19) & p値 \\
\hline 年齢(歳) & $58.9 \pm 19.1$ & $59.3 \pm 15.1$ & $59.1 \pm 20.3$ & N.S. \\
\hline 性別(男/女) & $13 / 6$ & $15 / 4$ & $13 / 6$ & N.S. \\
\hline 左室駆出率(\%) & & $44.3 \pm 21.4$ & $39.9 \pm 16.9$ & N.S. \\
\hline \multicolumn{5}{|l|}{ 基礎心疾患 } \\
\hline $\begin{array}{c}\text { 陳旧性心筋梗塞 } \\
\text { 前壁/後壁 }\end{array}$ & & $\begin{array}{c}14(74 \%) \\
7 / 7\end{array}$ & $\begin{array}{c}13(68 \%) \\
8 / 5\end{array}$ & \\
\hline $\begin{array}{c}\text { 前壁/後壁 } \\
\text { 拡張型心筋症 }\end{array}$ & & $\begin{array}{c}7 / 7 \\
4(21 \%)\end{array}$ & $\begin{array}{c}8 / 5 \\
2(11 \%)\end{array}$ & \\
\hline 拡張型心筋症 & & $4(21 \%)$ & $2(11 \%)$ & \\
\hline 肥大型心筋症 & & $1(5 \%)$ & $1(5 \%)$ & \\
\hline 心筋炎 & & & $1(5 \%)$ & \\
\hline QT延長症候群 & & & $2(11 \%)$ & \\
\hline \multicolumn{5}{|l|}{ 使用薬剂 } \\
\hline ACE阻害薬 & & 4 & 8 & N.S. \\
\hline アンギオテンシン II 受容体拮抗薬 & & 3 & 1 & N.S. \\
\hline 硝酸剤 & & 12 & 10 & N.S. \\
\hline ジギタリス & & 1 & & N.S. \\
\hline$\beta$ 遮断薬 & & 9 & 5 & N.S. \\
\hline Ca拮抗薬 & & 4 & 2 & N.S. \\
\hline \multicolumn{5}{|l|}{ 計測誘導 } \\
\hline V2誘導/V5誘導 & $9 / 10$ & $11 / 8$ & $9 / 10$ & N.S. \\
\hline
\end{tabular}

$\mathrm{N}$ 群 : 健常群, H群 : 心疾患群, VT/VF 群 : 持続性心室頻拍/心室細動群, N.S. : Not significant

は対象より除外した。使用薬剤は表に示す通りである.

2) QTVI

自動計測した RR 間隔より瞬時心拍数を求め, 10 分間全心拍の heart rate mean (HRm), heart rate variance $(\mathrm{HRv})$ を，また自動計測した同心拍のQT 間隔より QT mean $(\mathrm{QTm})$, QT variance $(\mathrm{QTv})$ を求め Bergerらの報告 ${ }^{18}$ に従い次の式でQTVIを求めた.

$\mathrm{QTVI}=\log _{10}\left[(\mathrm{QTV} / \mathrm{QTm})^{2} /\left(\mathrm{HRv} / \mathrm{HRm}^{2}\right)\right]$ QTVIは上式に示すようにQT 間隔の平均の2乗で除 し正規化した QT 間隔の分散と，同様に正規化した 心拍数の分散の比で表されており，心拍数の変動に 影響されない QT 間隔の変動指標と考えられる.

3) Frequency domain analysis

10 分間の RR 間隔データを Bergerらの方法 ${ }^{25}$ を用 いて $8 \mathrm{~Hz} て ゙$ 再サンプリングして時系列を作成した. 一方 QT 間隔の時系列は, 各々の $\mathrm{QT}$ 間隔の出現時 刻を対応するR波の出現時刻にあわせた。このタコ 276
グラムを直線で補間した後, $8 \mathrm{~Hz}$ で再サンプリング し, 再構成されたRR間隔データと時相が等しいデー 夕を作成した。これら時系列デー夕に対し高速フー リ工変換 (FFT) で周波数解析を行い，低周波数帯域 (LF : 0.04 0.15Hz), 高周波数帯域 (HF : 0.15 $0.40 \mathrm{~Hz})$ のパワー值を求めた.

さらにRR 間隔および $\mathrm{QT}$ 間隔のパワースペクト ラム解析および両者のクロススペクトラム解析よ $\eta, \mathrm{RR}$ 間隔と $\mathrm{QT}$ 間隔間の coherence を求めた. coherence の計算は Welchの方法 ${ }^{26}$ に従って 10 分間 のデータを 64 秒ごとに区切り, これらのデー夕を 32秒ずつずらして $50 \%$-overelapping法を用いてア ンサンブル平均によってパワー値, coherenceを求 めた. coherenceの誤差区間は区切ったデー夕の個 数が多ければ狭小化するが, 細分化しすぎると低周 波数成分の解析が不可能になる。 そこで我々は細分 化したデー夕長を 64 秒とし低周波数成分の解析を可 
能にし，しかも coherenceの誤差区間が小さくなる ようにした。 その結果, たとえば coherence值が 0.4 のときでも，その真の值は $0.4 \pm 0.33$ にあることにな り，推定した 0.4 は低いながらも相関があるという ことがいえる ${ }^{27}$. LF 領域も解析可能な coherence值 はLF領域およびHF領域のピーク值を用い比較した。

4) 統計学的検討

測定値は平均値士標準偏差で表し，3群間の比較 は連続変数の場合はOne-way ANOVA (Fisherの PLSD法)で，カテゴリー変数の場合は $\chi^{2}$ 検定で行っ た. $\mathrm{p}<0.05$ を統計学的有意差ありとした.
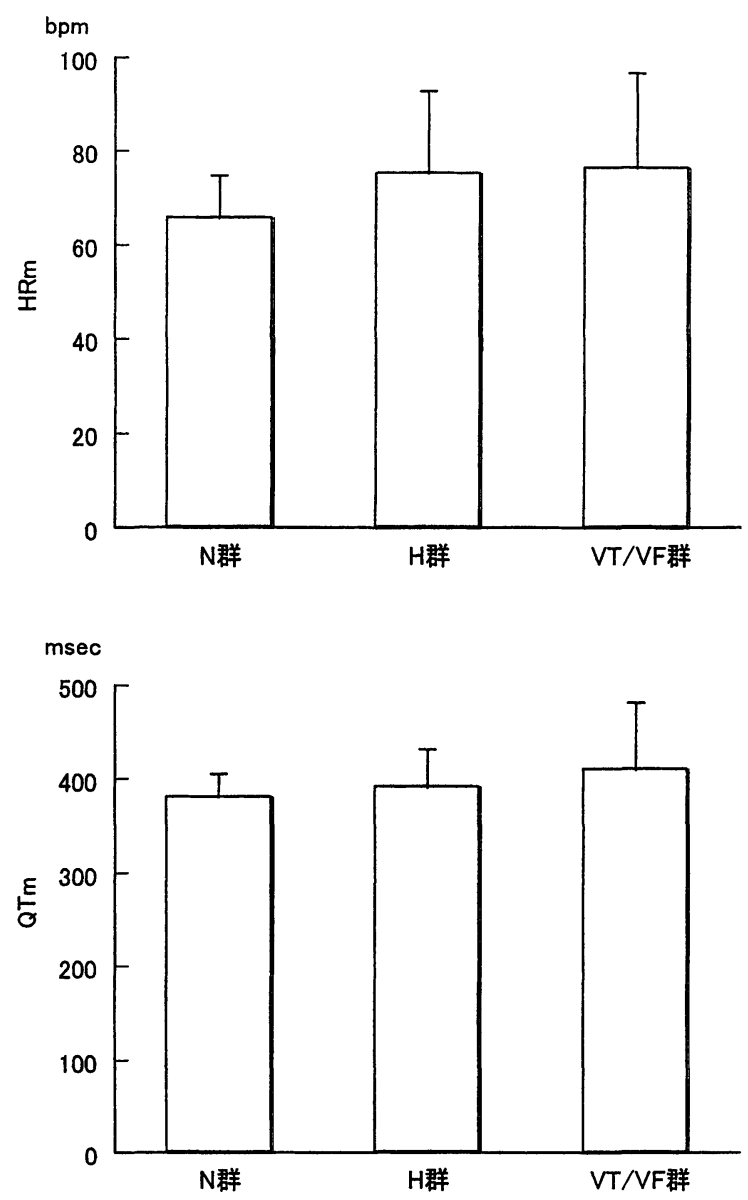

III. 結 果

\section{1. 患者背景}

患者背景を表に示した。平均年齢は $\mathrm{N}$ 群， $\mathrm{H}$ 群， $\mathrm{VT} / \mathrm{VF}$ 群でそれぞれ $58.9 \pm 19.1$ 歳, $59.3 \pm 15.1$ 歳, $59.1 \pm 20.3$ 歳で 3 群間に有意差はなかった。男女比 はそれぞれ $13 ： 6,15 ： 4 ， 13 ： 6$ で3群間に有意差 はなかった．左室駆出率は $\mathrm{H}$ 群 $44.3 \pm 21.4 \%$, $\mathrm{VT} / \mathrm{VF}$ 群 $39.9 \pm 16.9 \%$ で両群間に有意差はなかっ た. 使用薬郕は硝酸凨が最も多く $\mathrm{H}$ 群では 12 例, $\mathrm{VT} / \mathrm{VF}$ 群では 10 例で投与されていた，ACE阻害薬
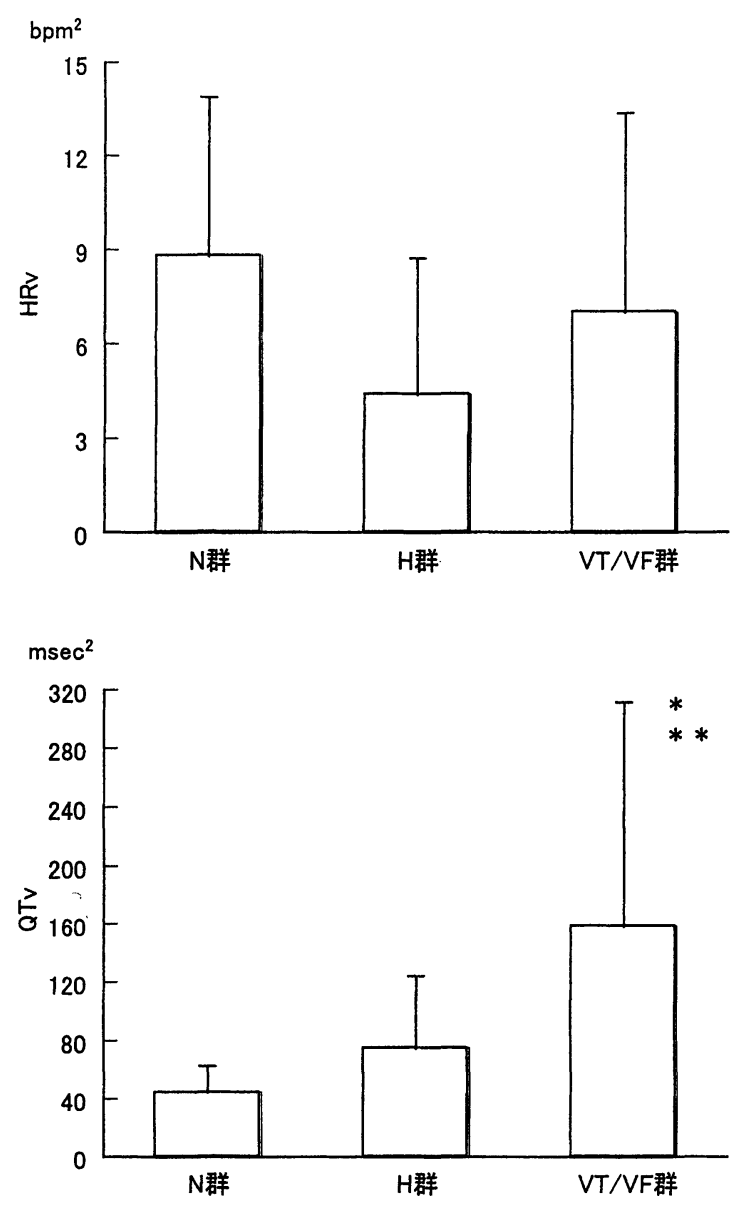

図1 各群の心拍数とQT間隔

HRm, HRv, QTmは3群間で統計学的有意差がなかったが, QTvはVT/VF群でN群, H群に比し有意に 大きかった.

$*: \mathrm{p}<0.05$ vs H群, **: $\mathrm{p}<0.0005$ vs N群, HRm : Heart rate mean, HRv : Heart rate variance,

QTm : QT mean, QTv : QT variance 
またはアンジオテンシン II 受容体拮抗薬は $\mathrm{H}$ 群 7 例, $\mathrm{VT} / \mathrm{VF}$ 群 9 例，ジギタリスは $\mathrm{H}$ 群 1 例， $\beta$ 遮断薬は $\mathrm{H}$ 群 9 例， VT/ VF 群 5 例， $\mathrm{Ca}$ 拮抗薬は $\mathrm{H}$ 群 4 例, $\mathrm{VT} / \mathrm{VF}$ 群 2 例で投与されていた。 各薬剤の使用率に 両群間で差は認めなかった。

\section{Time domain analysis}

$\mathrm{QT}$ 間隔は胸部 $\mathrm{V}_{2}$ 誘導または $\mathrm{V}_{5}$ 誘導のうち $\mathrm{T}$ 波が より認識しやすい誘導で計測した。その結果計測誘 導は $\mathrm{N}$ 群で $\mathrm{V}_{2}$ 誘導 9 例, $\mathrm{V}_{5}$ 誘導 10 例, 同様に $\mathrm{H}$ 群で 11 例，8例，VT/VF 群で 9 例，10例で 3 群間に差は なかった。

心拍数の比較では HRm は 3 群間で差がなく $(\mathrm{N}$ 群 vs H群 vs VT/VF群 : $65.5 \pm 9.0 \mathrm{bpm}$ vs $74.9 \pm$ $17.8 \mathrm{bpm}$ vs $76.1 \pm 20.5 \mathrm{bpm}$; NS), HRvはH群で小 さかったが統計学的有意差はなかった $(8.8 \pm$ $5.1 \mathrm{bpm}^{2}$ vs $4.4 \pm 4.3 \mathrm{bpm}^{2}$ vs $7.0 \pm 6.4 \mathrm{bpm}^{2}$; NS). $\mathrm{QT}$ 間隔の比較では QTm は3 群間で差がなかったが $(380.6 \pm 24.3 \mathrm{msec}$ vs $391.0 \pm 40.2 \mathrm{msec}$ vs $409.3 \pm$ $72.2 \mathrm{msec}$; NS), QTvはVT/VF群 (158.1 $\left.153.3 \mathrm{msec}^{2}\right)$ でN群 $\left(44.2 \pm 18.7 \mathrm{msec}^{2} ; \mathrm{p}<0.0005\right)$ ， $\mathrm{H}$ 群 $\left(74.9 \pm 49.4 \mathrm{msec}^{2} ; \mathrm{p}<0.05\right)$ に比し有意に大き かった(図1).QTVIはN群 $(-0.766 \pm 0.331)$ に比し $\mathrm{H}$ 群 $(-0.119 \pm 0.723), \mathrm{VT} / \mathrm{VF}$ 群 $(-0.117 \pm 0.692)$

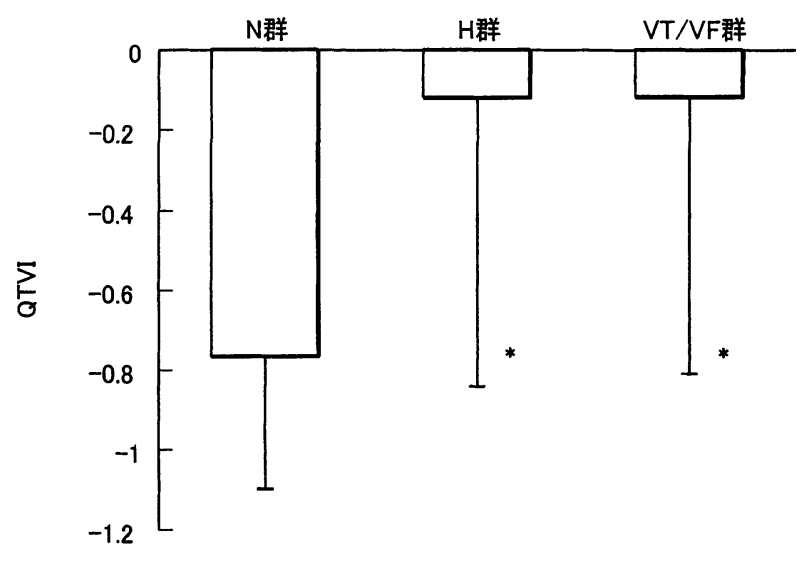

図2 各群のQTVI

QTVIはN群に比し H群，VT/VF群で有意に大きかった。 $*: \mathrm{p}<0.005$ vs N群

QTVI : QT variability index
で有意に大きかった $(\mathrm{p}<0.005)$ (図2).

3. Frequency domain analysis (図3)

$\mathrm{RR}$ 間隔の FFTの結果，LFのパワー值に 3 群間で

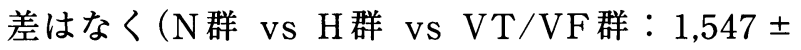
$1,499 \mathrm{msec}^{2}$ vs $879 \pm 1,034 \mathrm{msec}^{2}$ vs $1,130 \pm$ $1,327 \mathrm{msec}^{2}$; NS), HFのパワー值も3群間で統計学 的有意差はなかったが， $\mathrm{N}$ 群に比し $\mathrm{H}$ 群では低い傾 向を示した $\left(1,218 \pm 1,278 \mathrm{msec}^{2}\right.$ vs $431 \pm 440 \mathrm{msec}^{2}$ vs $961 \pm 894 \mathrm{msec}^{2}$; NS).

一方QT 間隔の FFT の結果はLFパワー值, HFパ ワー值ともにVT/VF 群では N 群，H群に比べ有意 に高值を示した（N群 vs H群 vs VT/VF群：LF： $28 \pm 12 \mathrm{msec}^{2}$ vs $42 \pm 31 \mathrm{msec}^{2}$ vs $88 \pm 92 \mathrm{msec}^{2}$; $\mathrm{p}<0.005$ vs $\mathrm{N}$ 群, $\mathrm{p}<0.05$ vs $\mathrm{H}$ 群 $; \mathrm{HF}: 45 \pm$ $21 \mathrm{msec}^{2}$ vs $67 \pm 52 \mathrm{msec}^{2}$ vs $163 \pm 176 \mathrm{msec}^{2} ; \mathrm{p}<$ 0.005 vs $\mathrm{N}$ 群, $\mathrm{p}<0.01$ vs $\mathrm{H}$ 群).

\section{Coherence (図4)}

LF 領域で coherenceがピーク值を示した周波数は 3群間で差はなかった (N群 vs H群 vs VT/VF群 : $0.080 \pm 0.026 \mathrm{~Hz}$ vs $0.076 \pm 0.033 \mathrm{~Hz}$ vs $0.075 \pm$ $0.030 \mathrm{~Hz}$; NS). 同領域での coherenceのピーク值は $\mathrm{N}$ 群，H群に比べVT/VF 群で有意に低值 (N 群 vs $\mathrm{H}$ 群 vs VT/VF群 : $0.329 \pm 0.156$ vs $0.305 \pm 0.186$ vs $0.163 \pm 0.072 ; \mathrm{p}<0.005$ vs $\mathrm{N}$ 群, $\mathrm{p}<0.01$ vs H群 $)$ であった (図4上段).

一方 HF 領域で coherenceがピーク值を示した周 波数はH群に比べVT/VF群で有意に高かったが $(\mathrm{N}$ 群 vs H群 vs VT/VF群 : $0.288 \pm 0.058 \mathrm{~Hz}$ vs $0.248 \pm 0.064 \mathrm{~Hz}$ vs $0.301 \pm 0.058 \mathrm{~Hz} ; \mathrm{p}<0.05$ vs $\mathrm{H}$ 群), 同領域での coherenceのピーク值は 3 群間で差 はなかった (N群 vs H群 vs VT/VF群 : $0.388 \pm 0.115$ vs $0.356 \pm 0.133$ vs $0.308 \pm 0.184$; NS) (図 4 下段).

\section{IV. 考察}

\section{QTVIの意義}

Berger らはtemporal dispersion of repolarization の新たな指標としてQT variability index (QTVI)を 提唱し, QTVIが拡張型心筋症患者で増大すること 

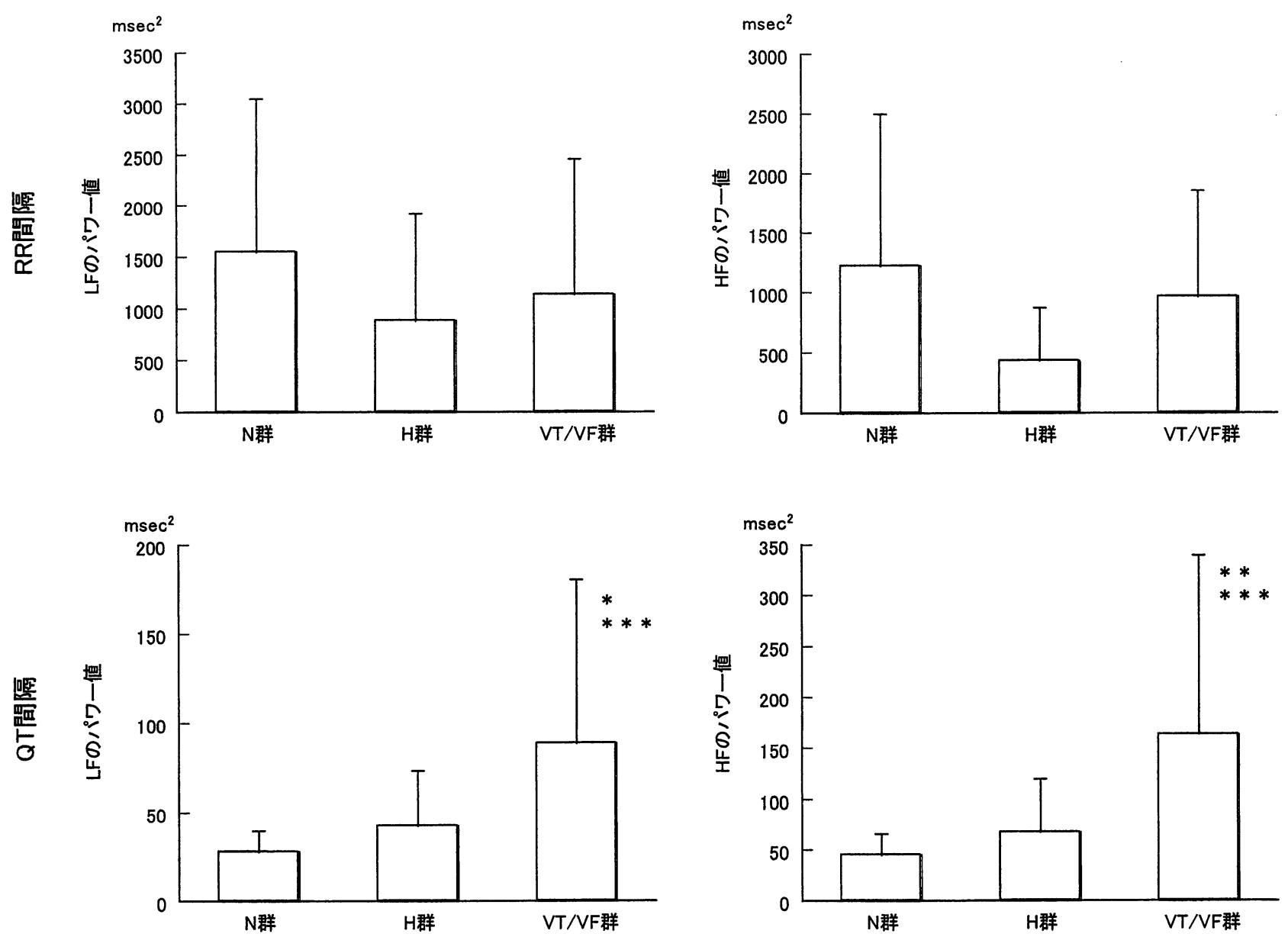

図3各群のRR間隔およびQT間隔の frequency domain analysis 指標

上段左が RR 間隔の LFパワー值，上段右がRR 間隔の HF パワー值，下段左が $\mathrm{QT}$ 間隔の LFパワー值，下 段右が $\mathrm{QT}$ 間隔の HFパワー値を示す．RR 間隔のパワー值に3群間で統計学的有意差はなかった，QT 間隔 はLFパワー値, HFパワー值ともにVT/VF群でN群, H群に比し有意に大きかった.

$*: \mathrm{p}<0.05$ vs $\mathrm{H}$ 群, $* *: \mathrm{p}<0.01$ vs $\mathrm{H}$ 群, $* * *: \mathrm{p}<0.005$ vs N群, LF $:$ Low frequency, HF :

High frequency

を示した ${ }^{18)}$ ＱT 間隔は心拍数の影響を受けるため, 心拍変動が大きい場合それを反映してQT間隔変動 は大きく，小さい場合は同様に小さくなることが考 えられ，QT 間隔絶対值のみの検討では過大または 過小評価をするおそれがある．しかしQTVIは，平 均 QT で正規化したQTの変動の大きさを同様に正 規化した心拍数の変動の大きさとの $\log$ 比で表した もので，心拍変動の影響を除いた QT 間隔の変動指 標であり，このような評価の䛊りを是正することが できる.AtigaらはQTVIが心室性不整脈患者, 特
に心室細動を含む心臓突然死患者 ${ }^{28)}$ や，肥大型心筋 症患者，特に心臓突然死をきたすことの多い遺伝子 型患者 ${ }^{29)}$ で増大することを示し，ハイリスク患者の 識別にQTVIが有用であることを示した.

今回我々はBergerらの報告に基づき QTVIを計測 したが，QT 間隔の計測は Bergerらとは異なる方法 を用いた. Bergerらはテンプレートとなる一心拍を 他の各心拍に重ね合わせ両心拍の T波の面積の差が 最小となるよう伸縮し, その伸縮率をテンプレート のQT 間隔に掛け合わせることにより各心拍の QT 

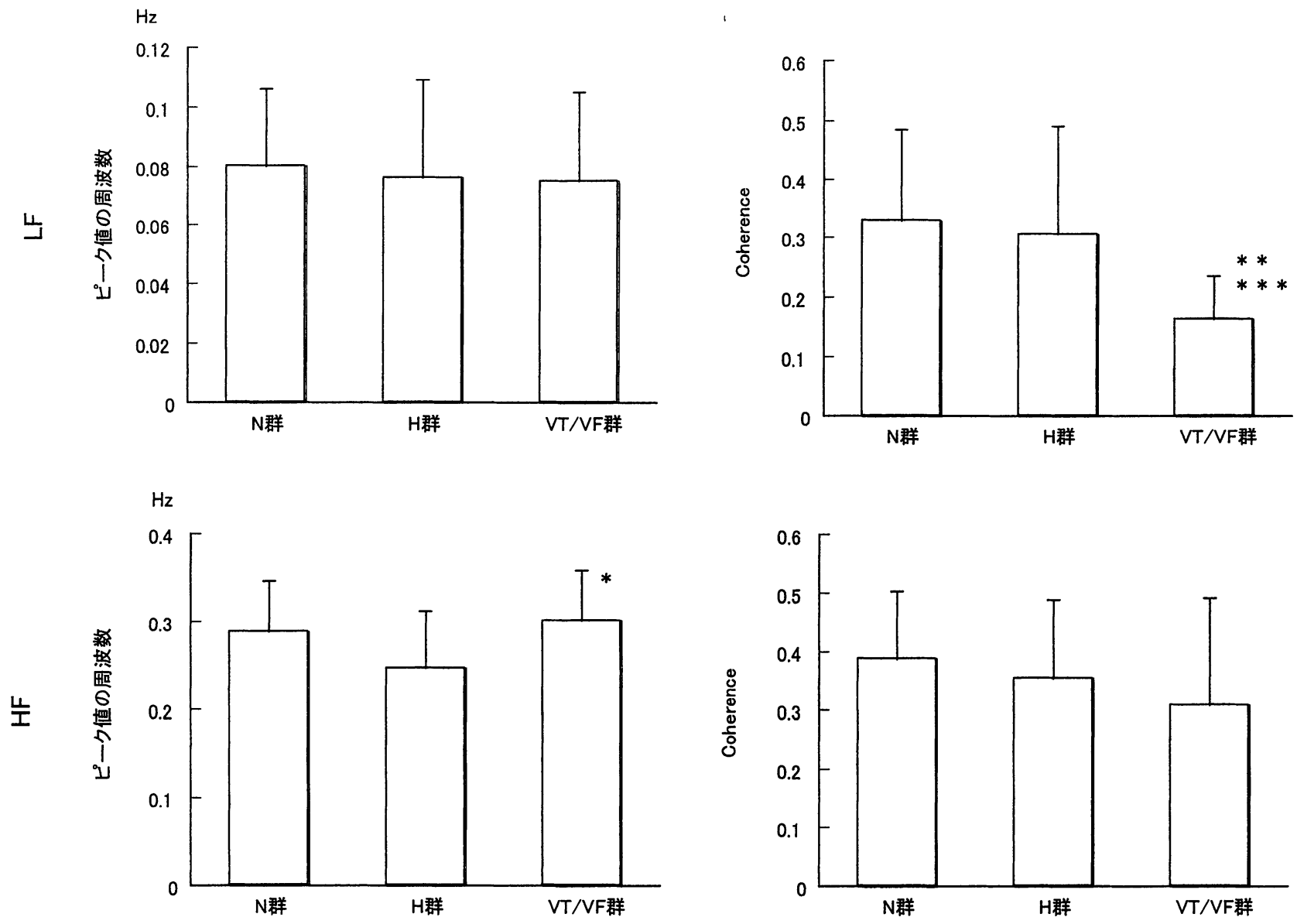

図4 各群の heart rate variability とQT variability の coherence

上段左がLF 領域で coherenceがピーク值を示した周波数, 上段右が LF 領域での coherenceのピーク值, 下段左がHF 領域で coherenceがピーク值を示した周波数，下段右がHF 領域での coherenceのピーク值を 示す. LF 領域では coherenceのピーク值の周波数は3 群間で差はなかったが, coherenceのピーク值は $\mathrm{VT} / \mathrm{VF}$ 群でN群, H群に比し有意に低值であった. HF 領域では coherenceのピーク值の周波数はVT/VF 群で $\mathrm{H}$ 群に比し有意に高值であったが, coherenceのピーク值は3群間で差はなかった.

$*: \mathrm{p}<0.05$ vs $\mathrm{H}$ 群, $* *: \mathrm{p}<0.01$ vs $\mathrm{H}$ 群, $* * *: \mathrm{p}<0.005$ vs $\mathrm{N}$ 群, LF : Low frequency, HF :

High frequency

間隔を求めた ${ }^{18)}$. 我々は循環動態全自動解析システ ム・フラクレット (大日本製薬社製)を用い，全心拍 で $\mathrm{Q}$ 波の開始点と $\mathrm{T}$ 波の終末点を決定し $\mathrm{QT}$ 間隔を 計測した。つまり我々の方法はQT 間隔の実測値を 用いており，より一般的であると考える.

今回の検討では, 正常群 (N群)に比し, 心疾患群 (H群)，VT/VF 群でQTVIは有意に大であり, 過 去の報告と同様の結果であった.つまり心疾患患者, 心室性不整脈患者で QT 間隔の時間的変動が大きく
なることが示された。しかし今回の検討では持続性 心室頻拍または心室細動を有しない心疾患群 $(\mathrm{H}$ 群) と有する群 $(\mathrm{VT} / \mathrm{VF}$ 群) との間にQTVIの差はなかっ たＨ群では統計学的有意差はなかったものの他の 2 群に比べHRvが小さく, 同群でQTVIが大きかっ た要因の一うとして心拍変動が小さかったことが考 えられた. HRvは先に示したようにQTVI計測式の 分母であり, 計算上HRvが小さければQTVIは大き くなる．しかしAtigaらはHRvとQTVIが相関せず， 
心室性不整脈予知因子としてQTVIが HRvよりも有 用であったとしている ${ }^{28)}$ 。一方 VT/VF群では QTV が他の 2 群に比し有意に大きく, QT 間隔絶対值の 変動が大きかったことが示され, $\mathrm{H}$ 群と VT/VF 群 ではQTVIが大きくなる要因が多少異なっていると 思われた。

\section{Frequency domain analysis $の$ 意義}

短時間の RR 間隔時系列データの周波数解析によ る heart rate variability (HRV) は自律神経活動の指

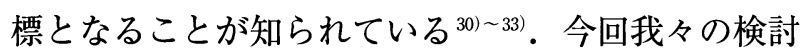
ではRR 間隔の周波数解析において LFのパワー值に 3群間で差はなく, HF のパワー值は統計学的有意差 はなかったものの $\mathrm{N}$ 群に比し $\mathrm{H}$ 群で低い傾向を示し た. 心疾患群でHFのパワー值が低下することは過 去の報告とも合致すると思われる ${ }^{34) ~ 36) . ~}$

一方 QT 間隔の周波数解析 (QTV)についての報告 はHRVに比べ少ないが，正常者においてQTVは HRVのパワー值に比べその絶対值は小さいもの $の^{21), 37), 38)} \mathrm{HRV}$ と同様の変動を示し, LFと HF の パワーがそれぞれ識別可能である ${ }^{21)}$,38), 39). また自 律神経緊張度の変化により QTVも変動し, 調節呼 吸による迷走神経緊張下ではLFは低下, HFは増大, ヘッドアップチルトによる交感神経緊張下ではLF は増大, HF は低下することが報告されている ${ }^{211}$. 今回の我々の検討でも HRVのパワー值に比べQTV のパワー值は小さかった.そして HRV 同様周波数 領域を LF 領域, HF 領域に分けての検討では, LF パワー值, HFパワー值ともにVT/VF群で大きかっ た。これは $\mathrm{VT} / \mathrm{VF}$ 群の $\mathrm{QT}$ 間隔変動が大きいこと が周波数解析においても示されたことを意味し，こ れには低周波数帯, 高周波数帯ともに影響を与えて いるものと考えられる.

\section{3. 心拍変動とQT間隔変動の coherence}

HRV と QTVの coherenceについての検討では, $\mathrm{VT} / \mathrm{VF}$ 群の coherenceのピーク值はLF領域におい て有意に低值を示した。一般に LF 領域 $(0.04$ $0.15 \mathrm{~Hz})$ はおもに交感神経活動の指標と考えられる が ${ }^{40) \sim 42), V T / V F}$ 群で同領域でのQTVのパワー值が
大きく, HRVとの coherenceが小さいことは，正常 群に比べVT/VF 群では $\mathrm{QT}$ 間隔変動への心拍変動 を介さない交感神経の影響が大きいことを意味する と考えられる。一方副交感神経活動の指標と考えら れる $\mathrm{HF}$ 領域 $(0.15 \sim 0.40 \mathrm{~Hz})^{31), 40), 42)}$ では，3群間で coherenceのピーク值に差を認めず，QTVへの心拍 変動を介した副交感神経の影響は 3 群とも同等であ ると考えられた。

これまでの $\mathrm{R} R$ 間隔変動と $\mathrm{QT}$ 間隔変動の coherenceについての報告では，正常者において coherenceが高く RR 間隔変動とQT 間隔変動の連動 が保たれている一方，心疾患患者でこの連動性が低 下するといわれている ${ }^{18,211,29), 38), 43)}$. Bergerらは拡 張型心筋症患者での coherenceの低下が，心室性不 整脈発生の基盤になりうるとしており，この現象が 細胞レベルでの electrical restitutionの変化によるの ではないかと述べている ${ }^{18)}$ ．またAtigaらも肥大型 心筋症患者で coherenceが小さく，特に突然死のリ スクが高い遺伝子型で最小であったと報告してい る ${ }^{29)}$.ただいずれも周波数領域が $0 \sim 0.2 \mathrm{~Hz}$ のみでの 検討であり，自律神経の影響についてまでは述べら れていない。 今回我々は LF 領域, HF 領域に分けて coherenceの検討を行い, LF 領域で VT/VF 群の coherenceが低下していたことは，心室性不整脈の 発生に心拍数への影響とは解離した心室再分極への 交感神経の直接的影響が関与していることを示唆す ると思われた。

\section{4. 問題点}

本研究の問題点の一つとして薬剤の影響があげら れる.今回対象として I 群， III 群抗不整脈薬内服例 は含めなかったが，H群およびVT/VF 群症例は各 種心血管作動薬を内服していた。これら薬剤が心室 再分極に影響をおよほしていたことは否定できな い. 特に $\beta$ 遮断薬は心室再分極への直接的影響およ び心拍数を介しての影響も考えられる．しかし今回 対象となった $\mathrm{H}$ 群，VT/VF 群には心機能低下例が 含まれており，薬剤の中断は困難であったこと， $\mathrm{H}$ 群と VT/VF 群では各薬剤の使用率に差がなかった 
ことから本研究では薬剤内服下で検討を行った.

次に計測誘導について, 本研究では $V_{2}$ 誘導, $V_{5}$ 誘 導のうち, より T波を認識しやすい誘導を選択し, 統一しなかった。これはT波を認識しやすい誘導の ほうがより正確にQT 間隔を計測できると考えたた めである．T波平低化や $\mathrm{T}$ 波と U波が融合している 誘導ではQT 間隔計測が困難であることも多く，そ の信頼性が低下する可能性がある。なお今回の検討 では3群間で計測誘導に差はなかった.

また本研究は単回の心電図のみを解析し, その再 現性については検討しなかった。心室再分極の spatial dispersionを表すQT dispersionはその再現 性が低いとする報告 ${ }^{11)}$ もるが, temporal dispersion については不明である. 今後 temporal dispersionの 再現性についての検討も必要であろう.

\section{V. 結 語}

今回我々は正常群 $(\mathrm{N}$ 群), 心疾患群 ( $\mathrm{H}$ 群), 致死 性心室性不整脈群 (VT/VF 群) について QT 間隔の 時間的変動を time domain, frequency domain 両者 より解析し検討を行った. Time domainの指標であ るQTVIはH群, VT/VF群でともに増大したが, その要因については両群間で異なっていた. 周波数 解析からはVT/VF 群でLF領域でのQTVのパワー 值が大きく, HRV との coherenceが小さいことより, QT 間隔変動への心拍変動を介さない交感神経の関 与が示唆された.

\section{[文献〕}

1) Willich SN, Maclure M, Mittleman M, Arntz HR, Muller JE : Sudden cardiac death : Support for a role of triggering in causation. Circulation, $1993 ; 87: 1442 \sim$ 1450

2 ) Bayes de Luna A, Coumel P, Leclerq JF : Ambulatory sudden cardiac death : mechanism of production of fatal arrhythmia on the basis of data from 157 cases. Am Heart J, $1989 ; 117: 151 \sim 159$

3 ) Bigger JT, Fleiss JL, Kleiger R, Miller JP, Rolnitzky LM : The relationship among ventricular arrhythmias, left ventricular dysfunction, and mortality in the 2 years after myocardial infarction. Circulation, $1984 ; 69: 250 \sim$ 258

4 ) Kleiger RE, Miller JP, Bigger JT, Moss AJ : Decreased heart rate variability and its association with increased mortality after acute myocardial infarction. Am J Cardiol, $1987 ; 59: 256 \sim 262$

5 ) Farrell TG, Paul V, Cripps TR, Malik M, Bennett ED, Ward D, Camm AJ : Baroreflex sensitivity and electrophysiological correlates in patients after acute myocardial infarction. Circulation, $1991 ; 83: 945 \sim 952$

6 ) Steinberg JS, Berbari EJ : The signal-averaged electrocardiogram : update on clinical applications. J Cardiovasc Electrophysiol, 1996 ; 7 : 972 988

7 ) Wilber DJ, Garan H, Finkelstein D, Kelly E, Newell J, McGovern B, Ruskin JN : Out-of-hospital cardiac arrest : Use of electrophysiologic testing in the prediction of long-term outcome. N Engl J Med, $1988 ; 318: 19 \sim 24$

8 ) Barr CS, Naas A, Freemn M, Lang CC, Struthers AD : QT dispersion and sudden unexpected death in chronic heart failure. Lancet, $1994 ; 343: 327 \sim 329$

9 ) Day CP, McComb JM, Campbell RWF : QT dispersion : an indication of arrhythmia risk in patients with long QT intervals. Br Heart J, $1990 ; 63: 342 \sim 344$

10) Perkiomaki JS, Koistinen MJ, Yli-Mayry S, Huikuei HV : Dispersion of QT interval in patients with and without susceptibility to ventricular tachyarrhythmias after previous myocardial infarction. J Am Coll Cardiol, 1995; $26: 174 \sim 179$

11) Kautzner J, Gang Y, Camm AJ, Malik M : Short-and long-term reproducibility of QT, QTc, QT dispersion measurement in healthy subjects. PACE, $1994 ; 17: 928 \sim$ 937

12) Fuller MS, Sandor G, Punske B, Taccardi B, MacLeod RS, Ershler PR, Green LS, Lux RL : Estimates of repolarization dispersion from electrocardiographic measurements. Circulation, $2000 ; 102: 685 \sim 691$

13) Malik M, Acar B, Gang Y, Yap YG, Hnatkova K, Camm AJ : QT dispersion does not represent electrocardiographic interlead heterogeneity of ventricular repolarization. J Cardiovasc Electrophysiol, $2000 ; 11$ : $835 \sim 843$

14) Brendorp B, Elming H, Jun L, Kober L, Malik M, Jensen GB, Torp-Pedersen C : QT dispersion has no prognostic information for patients with advanced congestive heart failure and reduced left ventricular systolic function. Circulation, $2001 ; 103: 831 \sim 835$

15) Rosenbaum DS, Jackson LE, Smith JM, Garan H, Ruskin JN, Cohen RJ : Electrical alternans and vulnerability to ventricular arrhythmias. N Engl J Med, 1994 ; 330 : 235 
241

16) Gold MR, Bloomfield DM, Anderson KP, El-Sherif NE, Wilber DJ, Groh WJ, Estes NA, Kaufman ES, Greenberg ML, Rosenbaum DS : A comparison of $\mathrm{T}$ wave alternans, signal averaged electrocardiography and programmed ventricular stimulation for arrhythmia risk stratification. J Am Coll Cardiol, 2000 ; 36 : 2247 2253

17) Hohnloser SH, Klingenheben T, Li YG, Zabel M, Peetermans J, Cohen RJ : T wave alternans as a predictor of recurrent ventricular tachyarrhythmias in ICD recipients : Prospective comparison with conventional risk markers. J Cardiovasc Electrophysiol, $1998 ; 9$ : $1258 \sim 1268$

18) Berger RD, Kasper EK, Baughman KL, Marban E, Calkins H, Tomaselli GF : Beat-to-beat QT interval variability : Novel evidence for repolarization lability in ischemic and nonischemic dilated cardiomyopathy. Circulation, $1997 ; 96: 1557 \sim 1565$

19) Schwartz PJ, Malliani A : Electrical alternation of the Twave : clinical and experimental evidence of its relationship with the sympathetic nervous system and with the long Q-T syndrome. Am Heart J, 1975 ; 89 : 45 50

20) Browne KF, Zipes DP, Heger JJ, Prystowski EN : Influence of the autonomic nervous system on the Q-T interval in man. Am J Cardiol, $1982 ; 50: 1099 \sim 1103$

21) Lombardi F, Sandrone G, Porta A, Torzillo D, Terranova G, Baselli G, Cerutti S, Malliani A : Spectral analysis of short term R-Tapex interval variability during sinus rhythm and fixed atrial rate. Eur Heart J, $1996 ; 17: 769 \sim 778$

22) Kowallik H, Braun C, Meesmann M : Independent autonomic modulation of sinus node and ventricular myocardium in healthy young men during sleep. J Cardiovasc Electrophysiol, $2000 ; 11: 1063 \sim 1070$

23) Nagai R, Nagata $\mathrm{S}$ : New algorithms for real-time, $24 \mathrm{hr}$ continuous and noise-adjusted power spectral analysis of heart rate and blood pressure fluctuations in conscious rats. Jpn J Pharmacol, 1996 ; 72 : 355 364

24) Nagai R, Nagata $S:$ New algorithmic-based digital filter processing system for real-time continuous blood pressure measurement and analysis in conscious rats. Comput Biol Med, 1995 ; 25 : 483 494

25) Berger RD, Akselrod S, Gordon D, Cohen RJ : An efficient algorithm for spectral analysis of heart rate variability. IEEE Trans Biomed Eng, 1986 ; 33 : 900 904

26) Bendat JS, Piersol AG : Random Data Analysis and Measurement Procedures (2nd Ed.). Wiley, New York,
1986.

27) Osaka M, Yambe T, Saitoh H, Yoshizawa M, Itoh T, Nitta S, Kishida H, Hayakawa H : Mutual information discloses relationship between hemodynamic variables in artificial heart-implanted dogs. Am J Physiol, 1998 ; 275 : H1419 H1433

28) Atiga WL, Calkins H, Lawrence JH, Tomaselli GF, Smith JM, Berger RD : Beat-to-beat repolarization lability identifies patients at risk for sudden cardiac death. J Cardiovasc Electrophysiol, 1998 ; 9 : 899 908

29) Atiga WL, Fananapazir L, McAreavey D, Calkins H, Berger RD : Temporal repolarization lability in hypertrophic cardiomyopathy caused by $\beta$-myosin heavy-chain gene mutations. Circulation, $2000 ; 101$ : $1237 \sim 1242$

30) Akselrod S, Gordon D, Ubel FA, Shannon DC, Barger $\mathrm{AC}$, Cohen RJ : Power spectrum analysis of heart rate fluctuation : a quantitative probe of beat-to-beat cardiovascular control. Science, $1981 ; 213: 220 \sim 222$

31) Pomeranz B, Macaulay RJB, Caudill MA, Kutz I, Adam D, Gordon D, Kilborn KM, Barger AC, Shannon DC, Cohen RJ, Benson H : Assessment of autonomic function in humans by heart rate spectral analysis. Am J Physiol, 1985 ; 248 : H151 H153

32) Pagani M, Lombardi F, Guzzetti S, Rimoldi O, Furlan R, Pizzinelli P, Sandrone G, Malfatto G, Dell'Orto S, Piccaluga $E$ : Power spectral analysis of heart rate and arterial pressure variabilities as a mareker of sympathovagal interaction in man and conscious dog. Circ Res, $1986 ; 59: 178 \sim 193$

33) Task force of the European society of cardiology and North American society of pacing and electrophysiology : Heart rate variability : Standards of measurements, physiological interpretation, and clinical use. Circulation, $1996 ; 93: 1043 \sim 1065$

34) Lombardi F, Sandrone G, Pernpruner S, Sala R, Garimoldi M, Cerutti S, Baselli G, Pagani M, Malliani A : Heart rate variability as an index of sympathovagal interaction after acute myocardial infarction. Am J Cardiol, $1987 ; 60: 1239 \sim 1245$

35) Binkley PF, Nunziata E, Haas GJ, Nelason SD, Cody RJ : Parasympathetic withdrawal is an integral component of autonomic imbalance in congestive heart failure : demonstration in human subjects and verification in a paced canine model of ventricular failure. J Am Coll Cardiol, $1991 ; 18: 462 \sim 472$

36) Lombardi F, Sandrone G, Mortara A, La Rovere MT Colombo E, Guzzetti S, Malliani A : Circadian variation of spectral indices of heart rate variability after myocardial infarction. Am Heart J, 1992 ; 123 : 1521 
1529

37) Sarma JSM, Singh N, Schoenbaum MP, Venkataraman $\mathrm{K}$, Singh BN : Circadian and power spectral changes of $\mathrm{RR}$ and QT intervals during treatment of patients with angina pectoris with nadolol providing evidence for differential autonomic modulation of heart rate and ventricular reporalization. Am J Cardiol, $1994 ; 74$ : 131 136

38) Lombardi F, Colombo A, Porta A, Baselli G, Cerutti S, Fiorentini $\mathrm{C}$ : Assessment of the coupling between RTapex and RR interval as an index of temporal dispersion of ventricular repolarization. PACE, $1998 ; 21$ : $2396 \sim 2400$

39) Nollo G, Speranza G, Grasso R, Bonamini R, Mangiardi L, Antolini R : Spontaneous beat-to-beat variability of the ventricular repolarization duration. J Electrocardiol, $1992 ; 25: 9 \sim 17$
40) Miliani A, Pagani M, Lombardi F, Cerutti S : Cardilovascular neural regulation explored in the frequency domain. Circulation, $1991 ; 84: 482 \sim 492$

41) Kamath MV, Fallen EL : Power spectral analysis of heart rate variability : a noninvasive signature of cardiac autonomic function. Crit Rev Biomed Eng, 1993 ; $21: 245 \sim 311$

42) Montano N, Ruscone TG, Porta A, Lombardi F, Pagani M, Malliani A : Power spectrum analysis of heart rate variability to assess the changes in sympathovagal balance during graded orthostatic tilt. Circulation, 1994 ; $90: 1826 \sim 1831$

43) Theres H, Romberg D, Leuthold T, Borges AC, Stangl $\mathrm{K}$, Bauman $\mathrm{G}$ : Autonomic effects of dipyridamole stress testing on frequency distribution of RR and QT interval variability. PACE, $1998 ; 21: 2401 \sim 2406$ 